\title{
Legal Implications of Dwindling Finances of Higher Education Institutions in Nigeria
}

\author{
Kayode Olatunbosun Fayokun \\ Obafemi Awolowo University, Ile-Ife, Nigeria
}

\author{
Segun Olugbenga Adedeji \\ University of Ibadan, Ibadan, Nigeria
}

\begin{abstract}
The constitutional provisions for education and the place of educational financing, all over the world, fall within the framework of the legal order. In Nigeria, financing of higher education has evoked dramatic, as well as ideological and political confrontations in the last two decades or so. The rationale sustaining this argument is compelling. A quality education, beginning with primary education, is fundamental to endow individuals with the capacity to successfully pursue their private goals, while at the same time equipping them with the knowledge and skills, as well as the values and attitudes, necessary to contribute effectively to the economic, social, and political development of their societies. All these require adequate financing of education at all levels. However, of all the problems facing Nigerian educational system today, none is more agonising and persistent as the dwindling financing of education, especially at the tertiary level. This paper, therefore, examines the weakness of higher education institutions (HEIs) in Nigeria in terms of their financial resource base. The paper relies on primary and secondary data to highlight inadequate funding as the primary factor in the myriads of challenges that have crippled HEIs from achieving their goals. The paper suggests methods of increasing the financial strength of these institutions towards improving the quality of higher education in Nigeria.
\end{abstract}

Keywords: higher education, funding, sustainability

\section{Introduction}

Historically, education in Nigeria had been championed by European Christian mission bodies and missionaries (Aladejana, Adesina, \& Adeleke, 2009). They established their own schools with their administrative and management structures ${ }^{1}$ (Ukeje \& Aisiku, 1982). The aim of the mission schools was of course the evangelisation of the native African soul ${ }^{2}$ (Fafunwa, 1974). Government intervention in education did not come until sometimes much later.

The inclination for higher education in Nigeria was actually initiated by E. R. J. Hussey when he introduced a three-tier system (made up of elementary, middle, and higher levels) of education (Ukeje \& Aisiku, 1982) in the Nigerian Legislative Council in 1930. This led to the establishment of the Yaba Higher College in

Kayode Olatunbosun Fayokun, Ph.D., lecturer, Department of Business Law, Obafemi Awolowo University.

Segun Olugbenga Adedeji, Ph.D., professor, Department of Education Management, University of Ibadan.

1 The introduction of Western education into Nigeria has been traced to the year 1842 when Rev. Thomas Birch Freeman of the Wesleyan Methodist Missionary Society arrived in Badagry, from Sierra Leone, for mission work. By 1860, the Church Missionary Society, the Baptist Mission, and the Roman Catholic Mission had each established their mission stations in Nigeria.

${ }^{2}$ According to Fafunwa (1974), each of these missions establishing their own schools used education as a means of conversion of people to Christianity. The schools laid emphasis on religion, character training or molding, and the learning of European ethics. They set up their own administrative and management structures, enrolled mostly their adherents and employed their own teaching staff. 
1932. The college offered courses in medicine, agriculture, engineering, surveying, and teacher education. The aim was to produce intermediate manpower qualifications for assistant positions in the various professions for the colonial administration.

Subsequently, and following the 1944 Elliot Commission Report on higher education in West Africa, the University College Ibadan was established in 1948 as an affiliate of the University of London. A year later, government set up a commission in 1949 to conduct a feasibility survey for technical education in order to meet the requirement of industry, commerce, and society. The commission recommended the establishment of the Nigerian College of Arts, Science and Technology with branches in Enugu, Ibadan, and Zaria. These institutions were set up as recommended and their enabling bill was introduced into the Nigerian legislature in April 1952. Thus, unlike primary and secondary education, higher education in Nigeria had, for several years, been treated as an aspect of public education.

Calls for the expansion of university education had been going on in the decade between 1950 and 1960 . The Ashby Commission of 1959 had recommended more government investment in education. The commission recommended the siting of two more universities, one in the north and one in the southern part of Nigeria. A minority report by Dr. S. D. Onabamiro (then Minister of Education, Western Nigeria), however, recommended the creation of regional universities in each of the existing three regions in the country (Fafunwa \& Aisiku, 1982). This was later capitalised upon by the Western Region government headed by Chief Obafemi Awolowo to establish its own university. Thus, the role of key figures in boosting the education drive of their fellow indigenes (in this case, the people of Western part of Nigeria) cannot be overemphasized. Later on, Chief S. O. Awokoya, as the Minister of Education, Western Region, declared in a parliamentary debate that "Educational development is imperative and urgent. It must be treated as a national emergency second only to war. It must move with the momentum of a revolution!” (Ukeje \& Aisiku, 1982, p. 218).

The ensuing education boom witnessed especially in the West must be understood and attributed to such visionary statements!

Apart from the University of Ibadan, three universities were sited in Nsukka, Lagos, and Zaria between 1960 and 1962. They acquired the campuses of the colleges of technology (earlier set up) to ease their take-off operations. The Western Region government had (on its own initiative) founded the University of Ife in 1962. It was formally opened in October of that year on the site of Ibadan branch of the Nigerian College of Arts, Science and Technology. Later on, upon the creation of the Mid-west Region in 1967, it became imperative for the central government to balance the equation by siting a university in the region. Thus, the establishment of the University of Benin in 1971 brought the number of first generation universities in Nigeria to six.

More opportunities in higher education were explored by government between 1970 and 1980 . The inclusion of the expansion of higher education in the Third National Development Plan (1975-1980) led to the creation of seven second generation universities in Jos, Calabar, Maiduguri, Port Harcourt, Ilorin, Kano, and Sokoto. Significantly, in 1979, the country adopted a new constitution modelled after the American presidential system upon return to civil rule on 1st October, 1979. The power of government under the constitution was shared between the three arms of legislative, executive, and judicial organs. The constitution was structured on a federal system with drawn up concurrent legislative lists for both federal and state legislatures. Buoyed by the inclusion of higher education as an item in the concurrent legislative list of the constitution, the scramble for 
state-owned or third generation universities began in earnest. The era was characterised by the emergence of such universities like Lagos State University (LASU), Ogun State University Ago-Iwoye, Ladoke Akintola University Ogbomoso, Ondo State University Akungba-Akoko, etc..

The liberalisation of higher education in the Fourth Republic opened the floodgates to the fourth generation universities floated mostly by independent promoters and mission bodies. Indeed, several operational licences to operate private universities had been granted within the nascent democratic era. As at 2011, there were 117 universities in Nigeria (comprising 36 federal, 36 state, and 45 private) running close to 1,450 programmes for close to 1.2 million registered students (5.4\% sub-degree, $87.5 \%$ undergraduate, and $7.1 \%$ postgraduate). The total academic staff, of close to 28,000 , is less than the estimated staff requirement of about 36,000 leading to a shortfall of about 8,000 academic staff with consequent negative impact on quality of programme delivery (Bamiro \& Adedeji, 2010). Besides, the number of polytechnics, monotechnics, colleges of education, and vocational institutes also increased significantly. This invariably made Nigeria the largest higher education market in Africa. Table 1 shows the number of tertiary education institutions in Nigeria by 2013.

Table 1

Nigeria Higher Education System in 2013

\begin{tabular}{lcrcccc}
\hline Type of institution & Federal & State & Private & Total & Enrolment & Percent (\%) \\
\hline Universities & 36 & 36 & 45 & 117 & $1,131,312$ & 58.4 \\
Polytechnics & 21 & 38 & 12 & 71 & 360,535 & 18.6 \\
Monotechnics & 23 & 2 & 2 & 27 & 36 & 4.7 \\
Colleges of agriculture & 17 & 19 & 0 & 50 & \\
Colleges of health technology & 9 & 40 & 1 & 50,259 & & \\
Vocational institutes & 0 & 0 & 69 & 69 & 79.3 \\
Colleges of education & 21 & 41 & 17 & 449 & $1,937,493$ & 100 \\
Total & 127 & 176 & 146 & & & \\
\hline
\end{tabular}

Note. Compiled by Olayinka and Adedeji (2013).

However, in spite of being Africa's largest higher education market, the system is still unable to admit all qualified applicants yearly because of limited carrying capacity. For instance, out of about 1,305,277 prospective candidates who applied for admission into Nigerian universities in 2010/2011 session, only 205,170 (or 16\%) were admitted. In fact, at the University of Ibadan, out of about 39,573 applicants who made the university their first choice and scored 50\% and above in the Unified Tertiary Matriculation Examination (UTME), only 3,692 (or 9.3\%) were eventually admitted into the university.

As earlier noted, for a long time, university education in Nigeria had been the exclusive preserve of government. During the military era, government pursued the policy of education as a state responsibility (with higher education in particular), as an aspect of public schooling at all levels. This started with the acquisition of the University of Ife by the Federal Government in 1975. The state governments followed suit by compulsorily acquiring all primary, secondary, and technical schools within their domain. Government's monopoly of education was overbearing and steeped up in draconian laws, leaving no room for private sector participation. The harshness of that policy can be illustrated by the two cases reported by Peretomode (1992): 
1. In Archbishop Anthony Olubunmi Okogie and Ors. v Attorney General of Lagos State ${ }^{3}$, on 26th March, 1980, the Lagos State Government issued a circular abolishing all private primary schools in Lagos State. The plaintiff, a trustee of Roman Catholic schools challenged the constitutionality of the government circular under section 259 of the 1979 Constitution and succeeded in maintaining his private rights. It was held that private citizens retain their constitutional rights to invest in education;

2. In Attorney General of Imo State v Dr. Basil Ukaegbu ${ }^{4}$, the plaintiff, a proprietor of a private university challenged the provisions of the Private Universities Abolition and Prohibition Decree (No. 19) of 1984, which abolished and closed down all existing private universities in the country. It was held that the decree was a contravention of constitutionally guaranteed right of private participation in economic activities and right to the protection of private property interests.

As the number of universities increased, the Nigerian National Universities Commission (NUC) was set up in 1975 with powers to control their affairs in terms of financing, staffing, conditions of service, undergraduate programmes, and postgraduate studies. Admission processes were centralised and academic programmes harmonised. The Joint Admission and Matriculation Board (JAMB) was set up in 1977 to handle all admission and matriculation matters of all Nigerian universities. JAMB's powers have been recently extended to cover all tertiary institutions in Nigeria. The result is that government by its laws and agencies exercise direct or indirect control and responsibility over the establishment, management, and finance of higher education institutions (HEIs) in Nigeria. This has placed enormous burden on government resources. The various attempts to reverse these trends and especially to restore the much eroded autonomy of the universities, may be considered in some quarters as a welcome relief, in view of the present financial predicament of educational institutions in Nigeria.

Given the rather slow pace of progress in higher education in the first half of the 20th century, one is tempted to ask: Why the sudden "mad rush" for higher education in the latter half of the same century? There was only one university in Nigeria between 1930 and 1960. Between 1960 and 1977, 12 universities came on board. The number of universities in Nigeria had risen to 106 in 2009. Between 1975 and 1999, the establishment, management, and control of higher education was the exclusive preserve of government and was particularly seen (during the military era) as the ultimate responsibility of the state. The military government saddled itself with overbearing responsibilities in primary, secondary, technical, and university education. That however did not guarantee adequate funding of HEIs.

\section{The Problem}

Today, higher education in Nigeria is facing multi-dimensional crises (top on the list of which is inadequate funding). These problems are not unrelated to the over-centralization and harmonisation schemes of previous years which made public education an expansive chunk of government expenditure. The overbearing influence of the state in the day-to-day university management (especially during the military era) has not augured well for the autonomy expected to be enjoyed by these institutions, unlike their counterparts in other parts of the world.

The obvious implication of government compulsory acquisition of all schools is that government has undertaken financial responsibilities as well. In the past, there seemed to have been some massive financial commitments on the part of governments to education which were not sustained. For instance, the Western

\footnotetext{
${ }^{3}$ Unreported, Court of Appeal, Lagos Division, 1981.

${ }^{4}$ Unreported, see Peretomode (1992).
} 
Region free education programme accounted for up to $82 \%$ of total expenditure of the government of the Western Region between 1955 and 1962 (Ukeje \& Aisiku, 1982). The free education programme was adopted by succeeding regimes in the same region but not with equal financial commitments. For the schools, resource inflows have rather decreased considerably rather than increase. In the case of the Federal Government, experience since the take over of universities does not indicate financial buoyancy for the government-owned universities in the face of dwindling governmental subventions. It may be observed that government expenditure on education has consistently nose-dived rather than take an upward swing. Financial commitments are not commensurate with financial responsibilities supposedly assumed.

\section{Related Literature}

The importance of increased financing of higher education in Nigeria is underscored by the link drawn between sustainable higher education and development initiatives for Africa. Experts maintain that quality education is a necessary purveyor for development drives (Adeyemi \& Adediran, 2009). The growth of higher education is perceived as crucial to various development initiatives across the African continent. This is particularly so for Nigeria which serves as a major indicator for growth in Africa.

Identified among the major development initiatives for Africa are: the Millennium Development Goals (MDGs), the World Summit on Sustainable Development (WSSD), and the New Partnership for Africa's Development (NEPAD). These development initiatives and agenda as adapted for Nigeria are particularly anchored by the National Economic Empowerment and Development Strategy (NEEDS) and more recently by the Vision 20-20-20 with the aim of harnessing all potentials in making Nigeria one of the 20 most industrialized nations in the world by the year 2020. All the development strategies recognize science, technology, engineering, and governance as key instruments to the achievement of the various development goals.

It is in this respect that HEIs are believed to be having a crucial role to play in the production and development of human capital needed at the highest levels to face the developmental challenges confronting a developing nation like Nigeria. To this end, there has been a renewed call for the revitalization of African universities. For instance, the African Union Conference of Heads of States and Governments in its Addis-Ababa Declaration, 2007, adopted the Consolidated Plan of Action for Science and Technology in Africa (2008-2013). This led to the establishment of the Pan African University (PAU) by the African Union Commission in 2008. The PAU idea was borne out of the vision of initiating, promoting, and networking research and development within Africa. Africa must develop world-class universities which will serve as the necessary launch pads for research and development and as the foundry for meaningful development initiatives. The point is that there is a growing nexus between sustainable qualitative higher education and meaningful development efforts.

\section{Challenges to Growth of HEIs}

As HEIs multiply in Nigeria, so are the challenges to their health and growth. Preeminent among the challenges threatening the growth of HEIs in Nigeria is the problem of inadequate funding. A myriad of other problems scuttle the day-to-day smooth running of academic programmes in the tertiary institutions. Some of these include the restiveness of the student and staff populations, violent demonstrations, disruptive campus cult activities, incessant closures, lack of equipment and tools, lack of rigorous academic challenges, lack of 
exposure of students, brain drain, and intellectual bankruptcy. All these problems are directly or indirectly related to the underlying problem of poor financing of higher education in Nigeria. As Bamiro and Adedeji (2010) observed:

The potential of higher education system to act as an engine of growth and development in Nigeria is being challenged by the long-standing problems of limited access, inadequate financing, poor governance, declining quality and relevance. These challenges have limited the performance of the Nigeria HEIs as agents of development through the performance of the key functions of teaching and research for knowledge creation and dissemination. (p. xi)

Stemming from their inadequate funding, perhaps one may add that for public universities in Nigeria, the incessant disruption of academic programmes and the brain drain syndrome are two major chronic challenges which their managers have to contend with. Without doubt, these challenges have severely constrained the realisation of the various development initiatives in the country. The obvious logical question that follows is: How do our HEIs confront these challenges? How do we revitalise the HEIs through sustainable financing towards nurturing our country along the path of national development?

\section{Characterisation of HEIs in Nigeria}

From a general overview, it is observed that the typology of HEIs in the education system determines their funding mechanism. Today, there are three categories of HEIs in Nigeria, namely, universities, polytechnics/monotechnics, and colleges of education. Due to the recent liberalisation policy of the Federal Government, many HEIs are springing up in Nigeria (Ukeje \& Aisiku, 1982). As at 2007, there were 104 universities. They consist of 27 federal, 36 state, and 41 private universities. There were 58 polytechnics; of which 21 are federal, 27 are state, and 10 are private institutions. Of the 47 monotechnics and specialised institutions, 32 are federal, 11 are state, and four are private-owned. The 79 colleges of education consist of 21 federal, 41 state, and 17 private institutions. The National Open University (NOUN), Army College, and the National Teachers Institute (NTI) also offer tertiary education programmes leading to the award of degrees or certificates.

The HEIs are regulated by the Federal Ministry of Education (Peretomode, 1992) through:

(a) NUC, for universities;

(b) National Board for Technical Education (NBTE), for polytechnic/monotechnics and technical colleges;

(c) National Commission for Colleges of Education (NCCE), for colleges of education.

These agencies perform such supervisory and regulatory functions over the HEIs, including establishment of the institutions, approval of courses and programmes, and determination and maintenance of minimum academic standards; accreditation of programmes and the monitoring of financial profiles.

\section{Funding Mechanism}

The funding mechanism of HEIs in Nigeria may be described in terms of income and expenditure patterns (Bamiro \& Adedeji, 2010). This is simplified in terms of resource inflows and outflows.

\section{Resource Inflows}

Resource inflows for HEIs in Nigeria are cast in the pattern of:

1. First stream funding:

(a) Government/proprietor allocations; 
(b) Education Trust Fund subventions;

(c) Funds received from other agencies of government.

2. Second stream funding:

(a) Student fees;

(b) Levies/charges.

3. Third stream funding:

(a) Grants from funding agencies;

(b) Endowment funds;

(c) Gifts and donations from friends/philanthropies;

(d) Investment income;

(e) Consultancy services;

(f) Others.

The funding mechanism may vary depending on the classification of the institution. For example, income generation for government-owned institutions takes the form of total or almost-total dependence on government allocations for survival. In addition, federal HEIs are expected to generate internally generated revenue equivalent to not less than $10 \%$ of the total allocation to them. They are nevertheless prohibited from charging tuition fees. To augment their resources, they are allowed limited charges/levies on students for provision of services, such as accommodation in halls of residence, sports, and limited contribution to meeting the cost of municipal services (i.e., water and electricity) or laboratory consumables for science-based students. Attempts to increase the charges/levies in the past have met with stiff opposition from students with the management of these institutions resolving to make do with whatever they can amicably "settle" with their students.

\section{Resource Outflows}

The resource outflows of HEIs in Nigeria generally take the following pattern:

1. Recurrent expenditure:

(a) Personnel costs (salaries and wages);

(b) Goods and non-personnel services (overheads, consumables, electricity, water supply, maintenance of facilities, etc.);

(c) Research and staff development;

(d) Staff and student welfare;

(e) General administration.

2. Capital expenditure (capital projects).

\section{Financial Shortfalls}

The financial weakness of federal HEIs becomes obvious when it is realised that salaries and wages in these institutions account for close to 85\% of their total expenditure (Bamiro \& Adedeji, 2010). For instance, the Federal Government's total budget allocation to 67 HEIs (comprising of 25 universities, 21 polytechnics, and 21 colleges of education) from 2006-2008 was NGN392.9 billion. This was shared as follows: $68.1 \%$ to universities, $18.9 \%$ to polytechnics, and $13.0 \%$ to colleges of education. An analysis of the various allocations to universities showed that, on average, allocations to personnel costs accounted for $84.7 \%$ of the total allocation. Goods and services took $4.6 \%$ while capital projects accounted for barely $10.7 \%$. The scenario 
painted by this analysis is that the old generation universities are sitting on decaying infrastructure while new generation universities have little room for expansion in terms of facilities. The University of Ibadan example evidently buttresses the point. The Federal Government's total allocation to the university for overheads in the 2005-2006 session was NGN197.7 million. The university's total expenditure on overheads in the same period was however NGN417.7 million. Also, the University of Ibadan runs 12 student hostels for which undergraduate students pay NGN14,000 for accommodation per session. The university is however spending close to NGN35,000 per bed space, running to about NGN21,000 subsidy per undergraduate student accommodated. The university bears similar subsidies on staff accommodated in university staff quaters. The same picture is replicated in most of the first and second generation universities. In consequence, the perennial shortfalls have to be funded from bank loans or internally generated revenue which are inelegantly secured and managed. These universities are weak in terms of planning, budgeting, and accountability. For example, when Chief Afe Babalola assumed position as Pro-Chancellor and Chairman of Council of the University of Lagos, one of his shocking discoveries was that the university was operating programmes and awarding degrees in a foreign country without the knowledge of Senate.

The crucial question will be: How does an educational institution translate its resource inflows and outflows to produce quality education output within the legal framework of its operations? With the realisation of the financial distress in the education sector, there must be a definite attempt to identify the challenges with a view towards designing pragmatic intervention approaches in combating them. For HEIs faced with dwindling resources, their resource outflows have to be re-captured in terms of what is deployed to:

(a) Core academic;

(b) Municipal/administrative support services;

(c) Staff and student welfare.

This is in line with the need to capture the level of deployment of resources to core business. According to the Honourable Minister of Education:

There is no doubt that the education sector is facing enormous challenges. The effective resolution of these challenges is a pre-condition for our nation's development.... In order to succeed, the nation needs world-class institutions. This calls for strategic investment towards improving the teaching and learning environment as well as the quality of lecturers in our institutions. (Bamiro \& Adedeji, 2010)

With the realisation of the distress in the education sector, there must be a definite attempt to identify the challenges with a view towards designing pragmatic intervention approaches in combating them.

\section{Implications of Dwindling Resources of HEIs}

There is a pressing need for the nation to address, in the overall context of Vision 20-20-20, the fundamental issues of strategic planning of the education sector. Some of the issues to address will include drawing up a template for HEIs for more efficient budgeting and financial allocation policies and practices, problems related to prompt release of funds, targeted funding to areas of great need, effective monitoring of expenditure, elimination of corruption, etc..

Managers of HEIs are to take steps to improve internal governance and efficiency-including in particular, the institutionalisation of transparency in the management of financial and other inputs into quality higher education. 
There is also a need to deepen and broaden the scope of private sector contribution of resources (including funds, materials, and ideas) to the development of government-owned higher institutions.

The government by enacting the National Minimum Standards and Establishment of Institutions Act 1993 has responded to the problem of access to higher education. That law gives a lee way to private sector involvement in university education as private enterprises, group of persons or even individuals can now establish and run a university in line with the guidelines laid down by the NUC. This led to the establishment of 38 private universities within five years (Bamiro \& Adedeji, 2010). However, the problem of cost differentia is yet to be attended to as students pay about 10 times or more in private universities for the same courses as their counterparts in public universities. One of the responsibilities of government under the constitution is to "direct its policy towards ensuring that there are equal and adequate educational opportunities at all levels" (Federal Republic of Nigeria, 1999). It is submitted that government should not be seen to abdicate its responsibilities to the citizens but should make education accessible to all rich and poor at all levels.

The over dependence of HEIs on government subvention for survival has its attendant unpleasant consequences. In the face of the over bearing influence of government in the governance of HEIs the first casualty was their autonomy. Appointments to the governing boards of HEIs are often seen as part of the largesse of political gladiators in the polity. Vice-chancellors were appointed and removed at pleasure by the government of the day. Some were even transferred across institutions like local inspectors.

In the recent times that government is affording HEIs some limited autonomy, the Education Trust Fund has become a major source of funding for government-owned HEIs. This has materialised into improved enhanced resource inflow for some selected HEIs, but the funds have been meagre and the intervention far apart.

\section{What a Good University Should Have?}

Many tertiary institutional ownership have or are intending to apply for provisional license of operation. Before granting a license, the NUC will inspect the tertiary institution. Table 2 is a suggested checklist of institutional capacity indicator which should help the NUC come to a decision of whether to accredit or not. This chart is adapted from the template provided by the Uganda National Council of Education for universities in Uganda.

Table 2

Checklist of Institutional Capacity Indicator

\begin{tabular}{|c|c|c|c|c|c|}
\hline Item & Ideal & Good & Acceptable & Can be improved & Unacceptable \\
\hline 1. Land for campus/urban & $10-30$ acres & 5-10 acres & 3-5 acres & 3 acres & Less than 3 acres \\
\hline 2. Land rural & 50 acres or over & $30-50$ acres & 20-30 acres & 10 acres & Less than 10 acres \\
\hline \multicolumn{6}{|l|}{ 3. Governance } \\
\hline (a) Present Council & In control of policy & Operational & In place & To be elected & Does not meet \\
\hline (b) Senate & \begin{tabular}{|l|} 
Supervises all \\
academic policies
\end{tabular} & Meets often & In place & $\begin{array}{l}\text { Meets when needs } \\
\text { arise }\end{array}$ & Does not meet \\
\hline (c) Administration & $\begin{array}{l}\text { Appointed legally } \\
\text { by council }\end{array}$ & \begin{tabular}{|l|} 
Respects \\
administrative \\
structures
\end{tabular} & $\begin{array}{l}\text { Consults with staff } \\
\text { students }\end{array}$ & Meets with staff & $\begin{array}{l}\text { Insensitive to staff } \\
\text { concern }\end{array}$ \\
\hline $\begin{array}{l}\text { (d) Staff and student } \\
\text { unions }\end{array}$ & $\begin{array}{l}\text { Staff and student } \\
\text { union involved fully }\end{array}$ & $\begin{array}{l}\text { Staff and student } \\
\text { union consulted }\end{array}$ & $\begin{array}{l}\text { Staff and student } \\
\text { union exist }\end{array}$ & $\begin{array}{l}\text { Staff and student } \\
\text { union present }\end{array}$ & $\begin{array}{l}\text { Staff and student } \\
\text { union absent }\end{array}$ \\
\hline
\end{tabular}


(Table 2 to be continued)

\begin{tabular}{|c|c|c|c|c|c|}
\hline \multicolumn{6}{|l|}{ 4. Infrastructure } \\
\hline (a) Classroom space & $\begin{array}{l}2.5 \mathrm{~m}^{2} \text { per one } \\
\text { student }\end{array}$ & $\begin{array}{l}2 \mathrm{~m}^{2} \text { per one } \\
\text { student }\end{array}$ & $\begin{array}{l}1 \mathrm{~m}^{2} \text { per one } \\
\text { student }\end{array}$ & $\begin{array}{l}1 \mathrm{~m}^{2} \text { per four } \\
\text { students }\end{array}$ & $\begin{array}{l}1 \mathrm{~m}^{2} \text { over five } \\
\text { students }\end{array}$ \\
\hline (b) Library space & $\begin{array}{l}2.5 \mathrm{~m}^{2} \text { per one } \\
\text { student }\end{array}$ & $\begin{array}{l}2 \mathrm{~m}^{2} \text { per one } \\
\text { student }\end{array}$ & $\begin{array}{l}1 \mathrm{~m}^{2} \text { per one } \\
\text { student }\end{array}$ & $\begin{array}{l}1 \mathrm{~m}^{2} \text { per four } \\
\text { students }\end{array}$ & $\begin{array}{l}1 \mathrm{~m}^{2} \text { per over five } \\
\text { students }\end{array}$ \\
\hline (c) Science laboratories & $3 \mathrm{~m}^{2}$ per one student & $\begin{array}{l}2.5 \mathrm{~m}^{2} \text { per one } \\
\text { student }\end{array}$ & $\begin{array}{l}1 \mathrm{~m}^{2} \text { per one } \\
\text { student }\end{array}$ & $\begin{array}{l}1 \mathrm{~m}^{2} \text { per four } \\
\text { students }\end{array}$ & $\begin{array}{l}1 \mathrm{~m}^{2} \text { per over five } \\
\text { students }\end{array}$ \\
\hline (d) Computer laboratory & $3 \mathrm{~m}^{2}$ per one student & $\begin{array}{l}2.5 \mathrm{~m}^{2} \text { per one } \\
\text { student }\end{array}$ & $\begin{array}{l}1 \mathrm{~m}^{2} \text { per one } \\
\text { student }\end{array}$ & $\begin{array}{l}1 \mathrm{~m}^{2} \text { per four } \\
\text { students }\end{array}$ & $\begin{array}{l}1 \mathrm{~m}^{2} \text { per over five } \\
\text { students }\end{array}$ \\
\hline (e) Administrative staff & $5 \mathrm{~m}^{2}$ per one staff & $\begin{array}{l}4 \mathrm{~m}^{2} \text { per } \\
\text { administrative } \\
\text { staff }\end{array}$ & $3 \mathrm{~m}^{2}$ per one staff & $\begin{array}{l}2 \mathrm{~m}^{2} \text { per } \\
\text { administrative } \\
\text { staff }\end{array}$ & $\begin{array}{l}1 \mathrm{~m}^{2} \text { or less per } \\
\text { staff }\end{array}$ \\
\hline (f) Academic staff & $5 \mathrm{~m}^{2}$ per one staff & $4 \mathrm{~m}^{2}$ per staff & $3 \mathrm{~m}^{2}$ per one staff & $\begin{array}{l}2 \mathrm{~m}^{2} \text { per } \\
\text { administrative } \\
\text { staff }\end{array}$ & $\begin{array}{l}1 \mathrm{~m}^{2} \text { or less per } \\
\text { staff }\end{array}$ \\
\hline (g) Sports field & $\begin{array}{l}\text { One field for } 500 \\
\text { registered students }\end{array}$ & $\begin{array}{l}\text { One field for } 1,000 \\
\text { students }\end{array}$ & $\begin{array}{l}\text { One field for } 1,500 \\
\text { students }\end{array}$ & \begin{tabular}{|l|} 
One field for \\
2,000 students
\end{tabular} & $\begin{array}{l}\text { One field for } \\
2,500 \text { or more }\end{array}$ \\
\hline (h) Facilities for disabled & All buildings & All classrooms & Only on a few & Planning to have & No plan at all \\
\hline $\begin{array}{l}\text { (i) Tennis court, swimming } \\
\text { pool, volleyball, hockey, } \\
\text { and cricket }\end{array}$ & $\begin{array}{l}\text { One field for each } \\
\text { sport for } 1,000 \\
\text { students }\end{array}$ & $\begin{array}{l}\text { One of each field } \\
\text { for each } 1,500 \\
\text { students }\end{array}$ & $\begin{array}{l}\text { One of each field } \\
\text { for } 2,000 \text { students }\end{array}$ & $\begin{array}{l}\text { One of each field } \\
\text { for 2,500 students }\end{array}$ & $\begin{array}{l}\text { One of each field } \\
\text { for over } 2,500 \\
\text { students }\end{array}$ \\
\hline (j) Conference hall & $\begin{array}{l}\text { One for } 500 \\
\text { registered students }\end{array}$ & $\begin{array}{l}\text { One for } 750 \\
\text { registered students }\end{array}$ & $\begin{array}{l}\text { One for } 1,000 \\
\text { registered students }\end{array}$ & $\begin{array}{l}\text { One for } 1,500 \\
\text { registered } \\
\text { students }\end{array}$ & $\begin{array}{l}\text { One for 2,000 } \\
\text { registered } \\
\text { students }\end{array}$ \\
\hline \multicolumn{6}{|l|}{ 5. Academic staff } \\
\hline \multicolumn{6}{|l|}{ (a) Staff/student ratio: } \\
\hline General & 1:15 & $1: 20$ & $1: 25$ & $1: 40$ & 1:50 or more \\
\hline Art/social sciences & 1:15 & $1: 25$ & $1: 30$ & $1: 50$ & $1: 50$ or more \\
\hline $\begin{array}{l}\text { Medicine, veterinary } \\
\text { pharmacy, dentist }\end{array}$ & 1:08 & $1: 15$ & $1: 20$ & $1: 25$ & $1: 26$ or more \\
\hline Science based & 1:10 & $1: 15$ & $1: 20$ & $1: 25$ & $1: 26$ or more \\
\hline Other professionals & 1:15 & $1: 20$ & $1: 25$ & $1: 30$ & $1: 30$ or more \\
\hline \multicolumn{6}{|l|}{$\begin{array}{l}\text { (b) Qualifications (staff } \\
\text { development) }\end{array}$} \\
\hline Ph.D. holders & $60 \%$ of staff & $50 \%$ of staff & $10-50 \%$ of staff & $10 \%$ of staff & $\begin{array}{l}\text { Less than } 10 \% \text { of } \\
\text { staff }\end{array}$ \\
\hline Master holders & $70 \%$ of more staff & $60 \%$ of staff & $50 \%$ of staff & $40 \%$ of staff & $\begin{array}{l}\text { Less than } 10 \% \text { of } \\
\text { staff }\end{array}$ \\
\hline $\begin{array}{l}\text { (c) Contract hours for } \\
\text { academic staff }\end{array}$ & 10 hours/week & 15 hours/week & 20 hours/week & 30 hours/week & $\begin{array}{l}30 \text { hours or more } \\
\text { a week }\end{array}$ \\
\hline \begin{tabular}{|l} 
(d) Percentage of \\
part-timers
\end{tabular} & $20 \%$ of staff & $30 \%$ & $35 \%$ & $40 \%$ & Over 50\% \\
\hline \multicolumn{6}{|l|}{ 6. Education facilities } \\
\hline $\begin{array}{l}\text { Student library book ratio: } \\
\text { Relevant and diversity }\end{array}$ & $1: 40$ & $1: 30$ & $1: 20$ & $1: 10$ & Less than $1: 10$ \\
\hline Computer student ratio & \begin{tabular}{|l|}
1 computer: 5 \\
students \\
\end{tabular} & $1: 10$ & $1: 20$ & $1: 25$ & Less than $1: 30$ \\
\hline Access to Internet & 1:20 hours access & 1:10 hours & 1:5 hours & 1:3 hours & None at all \\
\hline \multicolumn{6}{|l|}{ 7. Financial health } \\
\hline $\begin{array}{l}\text { Percentage of budget } \\
\text { received }\end{array}$ & $100 \%$ & $80 \%$ & $75 \%$ & $70 \%$ & Less than $50 \%$ \\
\hline
\end{tabular}


(Table 2 to be continued)

\begin{tabular}{|c|c|c|c|c|c|}
\hline $\begin{array}{l}\text { Percentage of deficit over } \\
\text { expenditure }\end{array}$ & Nil & Less than $10 \%$ & Less than $20 \%$ & Less than $25 \%$ & Over 35\% \\
\hline Proportion of budget & $50 \%$ & $60 \%$ & $65 \%$ & $70 \%$ & Over $75 \%$ \\
\hline $\begin{array}{l}\text { Spent on salaries } \\
\text { Percentage of income } \\
\text { derived from sees }\end{array}$ & $25 \%-35 \%$ & $40 \%$ & $45 \%$ & $50 \%$ & Over 75\% \\
\hline 8. Faculties for the disabled & $\begin{array}{l}\text { All facilities } \\
\text { available }\end{array}$ & $\begin{array}{l}\text { Most of the } \\
\text { facilities in place }\end{array}$ & $\begin{array}{l}\text { Facilities are being } \\
\text { put in place. }\end{array}$ & $\begin{array}{l}\text { Council has } \\
\text { endorsed their } \\
\text { construction } \\
\end{array}$ & $\begin{array}{l}\text { Nothing is in } \\
\text { place or being } \\
\text { planned }\end{array}$ \\
\hline 9. Gender sensitivity & $\begin{array}{l}\text { Comprehensive } \\
\text { affirmative action } \\
\text { regulation }\end{array}$ & $\begin{array}{l}75 \% \text { of the needed } \\
\text { rules and } \\
\text { regulations in place }\end{array}$ & $\begin{array}{l}\text { Council has } \\
\text { approved a } \\
\text { comprehensive list } \\
\text { of them }\end{array}$ & $\begin{array}{l}\text { Council has } \\
\text { endorsed their } \\
\text { construction }\end{array}$ & $\begin{array}{l}\text { Nothing is in } \\
\text { place or being } \\
\text { planned }\end{array}$ \\
\hline 10. Strategic plan & Being implemented & $\begin{array}{l}\text { Has been approved } \\
\text { by university } \\
\text { council }\end{array}$ & $\begin{array}{l}\text { Is before Senate or } \\
\text { council }\end{array}$ & Being drafter & $\begin{array}{l}\text { None is being } \\
\text { planned }\end{array}$ \\
\hline 11. Publications by staff & $\begin{array}{l}\text { Over } 10 \text { books a } \\
\text { year }\end{array}$ & 5-10 books a year & $1-5$ books a year & One book a year & $\begin{array}{l}\text { No publication at } \\
\text { all }\end{array}$ \\
\hline $\begin{array}{l}\text { 12. Research projects won } \\
\text { by staff }\end{array}$ & $\begin{array}{l}\text { Over } 10 \text { projects } \\
\text { won }\end{array}$ & 5-10 projects won & $1-5$ projects won & $\begin{array}{l}1 \text { project won a } \\
\text { year }\end{array}$ & $\begin{array}{l}\text { No research going } \\
\text { on }\end{array}$ \\
\hline $\begin{array}{l}\text { 13. Percentage of institution } \\
\text { graduates employed in year } \\
\text { of graduation }\end{array}$ & $100 \%$ & $80 \%$ & $40 \%-60 \%$ & $40 \%$ & $0-40 \%$ \\
\hline
\end{tabular}

\section{Conclusion}

HEIs in Nigeria are faced with numerous challenges, most of which are traceable to inadequate funding. Government and proprietors of HEIs must realise that education is capital intensive. There are yet to be world-class universities in Nigeria. If the frequent rankings of top universities in the world are anything to go by, Nigerian universities are not making any serious attempt to improve on their positioning. Sometimes, government inquiries are set up to discover the lapses without meaningful commitments to addressing them. The rot and decay that has accumulated over the years out of neglect can best be imagined.

Managers of HEIs are battling with a myriad of problems all the year round. Ranging from labour strikes, restiveness of students, examination malpractices, cult violence, incessant closure of campuses, inadequate facilities, and decayed infrastructure, to the problem of brain drain and low quality of teachers, many academic programmes are truncated or poorly executed. Paucity of funds and prudent management of scarce resources become crucial issues to address in the turning-around efforts and sustainability of quality education in Nigeria.

Good management models demand the organisation design strategies to minimise losses and maximise surpluses. Income and expenditure streams have to be kept within a workable frame. That means resource inflows and outflows are to be interacted to achieve growth and create more wealth. With this ultimate objective in mind, there is a need to balance total assets and liabilities so as to keep the organisation buoyant. Managers of HEIs (though not in business) are therefore called upon to be business-like. They are to ensure that their activities are streamlined to maintain sustainable financing of their institutions.

\section{References}

Adeyemi, B. A., \& Adediran, V. O. (2009). Issues and trends in Nigerian education system. In O. J. Ehindero, F. O. Aladejana, \& P. O. Jegede (Eds.), Principles and practice of education (p. 59). Ife: Institute of Education, Obafemi Awolowo University Press. 
Aladejana, F. O., Adesina, A. D. O., \& Adeleke, O. G. (2009). The growth of modern education in Nigeria. In O. J. Ehindero, F. O. Aladejana, \& P. O. Jegede (Eds.), Principles and practice of education (p. 40). Ife: Institute of Education, Obafemi Awolowo Press.

Bamiro, O. A., \& Adedeji, O. S. (2010). Sustainable financing of higher education in Nigeria (SUFIHEN): A conceptual framework. Ibadan: Ibadan University Press.

Fafunwa, A. B., \& Aisiku, J. U. (1982). Education in Africa: A comparative survey. London: George Allen \& Unwin Ltd..

Fafunwa, B. (1974). History of education in Nigeria. London: George Allen \& Unwin Ltd..

Fayokun, O. K., \& Adedeji O. S. (2006). Legal issues in educational management in Nigeria. In J. B. Babalola, A. O. Ayeni, S. O. Adedeji, A. A. Sulaiman, \& M. O. Arikewuyo (Eds.), Educational management: Thoughts and practice. Ibadan: Codat Publications.

Federal Republic of Nigeria. (1999). Constitution of the Federal Republic of Nigeria, 1999: Chapter II fundamental objectives and directive principles of state policy. Retrieved from http://www.waado.org/nigerdelta/documents/ConstitutionalMatters/ 1999Constitution/ChapterTwo.html

Olayinka, I., \& Adedeji, S. (2013, May 16). Higher education and governance reforms in Nigeria: University autonomy. Paper presented at The UNESCO/IIEP Policy Forum on Governance Reforms in Higher Education in Africa, Nairobi, Kenya.

Peretomode, V. F. (1992). Education law: Principles cases \& materials on schools. Owerri: International Universities Press.

Ukeje, O., \& Aisiku, J. U. (1982). Education in Nigeria. In A. B. Fafunwa, \& J. U. Aisiku (Eds.), Education in Africa: A comparative survey. London: George Allen \& Unwin Ltd.. 